\title{
Shallot Farmers' Adaptation Towards Climate Change in Larangan Village, Brebes
}

\author{
Tri Utami Solichah ${ }^{1 *}$ and Kordiyana K. Rangga ${ }^{2}$ \\ 1 Department of Magister of Environmental Science, Padjadjaran University, West Java, \\ Indonesia \\ 2 Department of Agribusiness, Faculty of Agriculture, University of Lampung, Bandar \\ Lampung, Indonesia \\ *e-mail: solichah.tri@gmail.com
}

\begin{abstract}
This research examined the issue related to farmers' adaptation towards climate change phenomenon, specifically for farmers whose main commodity was shallot, in Larangan, a village in Larangan Sub District, Brebes District. The purpose of this research was to understand the adaptation strategies, which were done by the shallot farmers in their planting field, toward the climate change phenomenon. The study used a combined method (qualitative and quantitative method). The result of this research showed that the adaptation strategies of shallot farmers toward climate change on direct case consisted of several aspects; cultivation aspect (changing the planting pattern, using the pump, changing the land management, and increasing the utilization of pesticide), agricultural financing aspect (storing shallot in para-para), and cultural diversification aspect (horizontal diversification/planting other commodities and seasonal transmigration). While on the indirect case, there were several strategies grouped by aspects of; cultivation aspect (using the superior seed), and agricultural diversification aspect (merantau).
\end{abstract}

\section{Keywords}

adaptation, climate change, phenomenon, shallot, farmer

\section{Introduction}

Agriculture is a sector that is agitated towards the negative effects of climate change. It happens because it depends mostly on climate and weather, especially in developed countries [1]. Agriculture in developed countries is influenced by two factors, they are (1) lack of physical and non-physical infrastructures to prevent the negative effects of climate change phenomenon; and (2) the tendency of climate change which relatively occurs in most equatorial regions or developed countries including Indonesia [1].

Adaptation is identified as one of the policy strategies in

Citation: Solichah, T. U., Rangga, Kordiyana K. (2018). Shallot Farmers' Adaptation Towards Climate Change in Larangan Village, Brebes. In T. R. Nuringtyas, A. C. Sukartiko, \& A. Isnansetyo (Eds.), UGM Digital Press Life Sciences: Vol. 1. Proceeding of the 2nd International Conference on Tropical Agriculture, (pp. $45-55$ ) decreasing the negative effects of climate change [1, 2]. Adaptation towards climate change can be planned or carried out autonomously (spontaneously). The spontaneous action is the unconscious adaptation towards climate stimulation. It is triggered by the use of natural system ecology and is triggered by the market of welfare changes in the human system [3]. The forms of adaptations used in farming are the use of the new variety of plant and livestock which are more suitable with the dry condition; irrigation; plant diversification; 
mixed farming system (plant and livestock); and the alteration of planting time [2, 4, 5].

Several kinds of research on farmers' adaptation towards climate change have been conducted, but the researchers limit their research only on the farming commodity in general. The examples of those researches are conducted by Nurasa and Iqbal [6], Husena [7], Ifeaniobi et al. [8], and Deressa et al. [9]. Those researches describe the forms of adaptation by farmers in food crops commodities. In addition to food crops, Kurniawati [10] in the previous study examined the adaptation towards climate change by vegetable farmers in general. Moreover, Oyekale and Oladele [11] also conducted research on adaptation to climate change by chocolate farmers. The research describes the influenced factors of adaptation to climate change by chocolate farmers. Unfortunately, the study has not examined the forms of farmers' adaptation and knowledge.

According to the description previously, researches about adaptation towards climate change in farmers who grow typical commodities in Indonesia is still rare. Consequently, it is important to conduct the research about adaptation strategy towards climate change on local commodities.

The research is conducted in Larangan, a village in Larangan Sub District, Brebes District where the farmers produce one of the biggest shallot commodities in Brebes. The study aims to find out the shallot farmers' adaptation to climate change as one of the local commodities in Larangan Village, Larangan Sub District, Brebes District.

\section{Methods}

The location of the study was determined purposively in Larangan Village, Larangan Sub District, Brebes District. The selection of this location is done because Larangan District is one of the production centers of shallot in the Brebes District. In addition, the farmers in Larangan Village are active in following agricultural extension/information activities (based on information from extension staff), so it is necessary to see how far the shallot farmers' adaptation behavior to climate change phenomenon that occurs in the area of cultivation.

Data collection techniques were conducted by structured interviews, in-depth interviews and also field observation. In-depth interviews conducted to determine the respondent's behavior in the adaptation by asking the farmers about the strategic process and form of their cultivation. Observation techniques were conducted by recording and observing farmers' adaptation directly to obtain accurate data about how the practice of shallot farming and farmers' adaptation to climate change.

There were 99 respondents. This number was attained from the calculation of 14.500 household heads of the farmers using the Taro Yamane sampling formula from Taro Yamane [12] with a 10\% error rate $(d=0.1)$. Descriptive statistics using SPSS program was done to analyze the data. Data collection was conducted in May-August 2013.

The data required in this study is taken by determining the research variables. Then the variables were taken down to sub-variables as measured to the type of data. The list of Variable Operationalization is presented in Table 1. 
Table 1 Operationalization Variable [13]

\begin{tabular}{|c|c|c|c|c|c|}
\hline $\begin{array}{c}\text { Target of } \\
\text { Study }\end{array}$ & Variable & Sub-variable & $\begin{array}{l}\text { Type of } \\
\text { Data }\end{array}$ & $\begin{array}{c}\text { Data } \\
\text { Collection }\end{array}$ & $\begin{array}{c}\text { Data } \\
\text { Resource }\end{array}$ \\
\hline \multirow{4}{*}{$\begin{array}{l}\text { Strategy of } \\
\text { shallot } \\
\text { farmers' } \\
\text { adaptation } \\
\text { towards } \\
\text { climate } \\
\text { change }\end{array}$} & $\begin{array}{l}\text { (1) Agricultural } \\
\text { cultivation }\end{array}$ & $\begin{array}{ll} & \text { Changing cropping pattern } \\
\text { - } & \text { Changing cropping time } \\
\text { - } & \text { Usage of superior seeds } \\
\text { - } & \text { Repair of irrigation system } \\
\text { - } & \text { Usage of fertilizer and pesticide } \\
\text { - } & \text { Land processing }\end{array}$ & Primer & $\begin{array}{c}\text { Interview with } \\
\text { questionnaire }\end{array}$ & Farmers \\
\hline & $\begin{array}{l}\text { (2) Agricultural } \\
\text { Financing }\end{array}$ & $\begin{array}{l}\text { - } \quad \text { Informal loan } \\
\text { insurance } \\
\text { - Storage of crops } \\
\text { - } \quad \text { Direct production sales }\end{array}$ & Primer & $\begin{array}{c}\text { Interview with } \\
\text { questionnaire }\end{array}$ & Farmers \\
\hline & $\begin{array}{l}\text { (3) Agricultural } \\
\text { diversification }\end{array}$ & $\begin{array}{l}\text { - } \\
\text { - } \quad \text { Business diversification (trade, wage } \\
\text { laborers, craftsmen, breeders) } \\
\text { - Migration }\end{array}$ & Primer & $\begin{array}{c}\text { Interview with } \\
\text { questionnaire }\end{array}$ & Farmers \\
\hline & $\begin{array}{l}\text { (4) Agricultural } \\
\text { knowledge } \\
\text { and social } \\
\text { network }\end{array}$ & $\begin{array}{l}\text { - } \quad \text { Knowledge about planting and } \\
\text { cropping time } \\
\text { - } \quad \text { Knowledge about climate and its } \\
\text { handling } \\
\text { - } \quad \text { Participation in agricultural training } \\
\text { - } \quad \text { Participation in farmers groups }\end{array}$ & Primer & $\begin{array}{l}\text { Interview with } \\
\text { questionnaire }\end{array}$ & Farmers \\
\hline
\end{tabular}

\section{Result and Discussion}

\subsection{Farmer's Adaptation Strategies Towards Climate Change}

Based on interviews and observations, there are three groups of farmers' adaptation strategies, namely: (1) Direct adaptation due to climate change, (2) Indirect adaptation due to climate change, and (3) Adaptation that is not done by respondents not because of climate change. Based on the operationalization of variables referring to Below et al. [13], a study was conducted on 4 aspects, namely agricultural cultivation aspect, agriculture financing aspect, agricultural diversification aspect, and knowledge aspect and agricultural social network.

\subsubsection{Agricultural Cultivation Aspect}

Based on interviews and observations with farmers and agricultural extension workers in the study sites, not all adaptation strategies in the agricultural cultivation aspects based on the literature were practiced for reasons of adaptation to the impacts of climate change. Adaptation strategies undertaken by farmers due to climate change conditions (especially climate change occurring at rising temperatures, rainfall, rainy days) are changing cropping patterns, using irrigation systems and water pumps, transforming soil tillage, and using chemical pesticides. 
Table 2 Farmers' Adaptation Strategy in Agricultural Cultivation Aspect

\begin{tabular}{clccc}
\hline No & \multicolumn{1}{c}{ Adaptation Strategy } & Yes (\%) & No (\%) & Total Amount (\%) \\
\hline $\mathbf{1}$ & Changing cropping pattern *) & $58(58,6)$ & $41(41,4)$ & $99(100)$ \\
$\mathbf{2}$ & Usage of superior seeds & $93(93,9)$ & $6(6,1)$ & $99(100)$ \\
$\mathbf{3}$ & Irrigation system *) $_{\mathbf{4}}$ ) & $97(98,0)$ & $2(2,0)$ & $99(100)$ \\
$\mathbf{4}$ & Usage of organic fertilization & $21(21,2)$ & $78(78,8)$ & $99(100)$ \\
$\mathbf{5}$ & Usage of vegetative pesticide & $9(9,1)$ & $90(90,9)$ & $99(100)$ \\
$\mathbf{6}$ & Changing soil tillage*) & $72(72,7)$ & $27(27,3)$ & $99(100)$ \\
$\mathbf{7}$ & Others (Usage of chemical pesticide) $\left.{ }^{*}\right)$ & $81(81,8)$ & $18(18,2)$ & $99(100)$ \\
\hline$*$ F Farmers' strategy due to the climate change phenomenon & & &
\end{tabular}

\subsubsection{Changing Cropping Pattern}

The planting pattern that is usually done by farmers is paddy-shallot-shallot. However, because of the uncertain wind and rainfall conditions, some farmers change the cropping pattern to paddy-paddy-shallotshallot or sweet corn-shallot-shallot- shallot-paddy. Changes in cropping patterns are conducted for two reasons: the changing climate variables and the high price of shallot seeds. And it is likely that both can be interrelated reasons.

Since 2007, climatic conditions in Larangan Village are uncertain. Rainfall and rainy days in the agricultural area of Larangan Village have increased relatively. In addition, the beetle wind relatively rarely blows. The beetle wind is a mainstay wind for shallot farmers which can give a positive influence on the growth of shallot. The wind helps the farmers in maintaining the temperature in the cultivation area of shallot by keeping it dry and not too moist. The uncertain climate conditions are often found throughout July - August 2010.

Adaptation by changing cropping pattern does not occur in some farmers in Larangan Village. There are $41.4 \%$ of respondents of shallot farmers, especially those with large capital (which includes farmers with the land area above $1 \mathrm{Ha}$ and a small number of farmers with a land area of 0.51-1 Ha), decide to continue to plant shallot throughout the season. They do this because the sale price of shallot at this time is quite higher compared to the previous years. They do not care if the tonnage of shallot will be decreased in the rainy season because of economic motivation. They will get a higher selling price advantage from the cultivation of shallot rather than the cultivation of paddy. Their strategy to reduce the risk of lower shallot tonnage due to the disease is by provisioning of pesticides more frequently which means it will raise the cost especially for the purchase of pesticide drugs.

\subsubsection{Usage of Superior Seeds}

Most respondents $(93,3 \%)$ use superior seeds of Bima shallots. Related to the climate response, especially from the weather aspect, Bima shallot has a short life of cropping. It can be cropped after 60 days of planting. Planting Bima shallot will be more advantageous for farmers to minimize the risk of cropping failure. For example, the shallot farmers had a loss since 2005, when the rainy season was longer than usual. It made the farmers had to wait until 3 months to cultivate the crops.

However, Bima shallot also has its weakness. It cannot resist when it is stored for at least 2 months. When it is stored for more than 2 months, it will be rotten or grow leaves. In reality, the common variety of shallot found in the market is Bima shallot, thus the farmers have no choice except to plant Bima shallot.

The strategy of superior seeds usage according to Below et al. [13] is one of the adaptation strategies towards climate change in the management of agricultural cultivation aspect. The strategy uses the benefit of technology such as seeding technology. However, not all country or region have engineered the superior seeds which can resist the negative effect of climate change. In this study of this Larangan Village, the adaptation of superior seeds usage was not adapted in other countries.

Based on the information gained from the informants, a special variety of shallot which can resist climate change has not been found yet. Bima shallot can survive because of the government of Brebes District insists on producing local shallot rather than importing shallot from other countries. The farmers are pushed to store $1 / 3$ of the Bima shallot crops then they are used as seeds for the following planting time. In conclusion, the usage of Bima superior seeds actually is not farmers' adaptation strategy. It is because the Bima shallot is the local commodity then the government is willing to keep producing them. 


\subsubsection{Usage of Irrigation and Water Pump}

The usage of irrigation and water pump is a form of farmers' adaptation in facing the problem of water shortage due to drought. In the rainy season, farmers rely on technical and semi-technical irrigation from the river. However, when the dry season comes in September-October, farmers get the water by pumping from wells using diesel. The pumping of the water well costs much more than irrigation during the rainy season. To irrigate $0.5 \mathrm{Ha}$ of land required gasoline with a total of 200 litter until harvest time arrives. The need for pumped well water has increased in the last 5 years due to higher air temperature. The rising temperature caused a longer drought period during the dry season, Even though the dry season lasts shorter than the rainy season. Based on interviews with extension agents and field observations, it can be concluded that this strategy is an adaptation strategy towards climate change because there is increasing use of pump water wells in the dry season with a 5-6\% increase.

\subsubsection{Usage of Pesticide and Fertilization}

Climate change, especially the increasing air temperature causes the higher population of Spodoptera litura or Grayak caterpillar as the main pest of shallot. As a result, the high population of Spodoptera litura caterpillar caused crop failure. In coping with this problem, farmers eradicate Spodoptera Litura caterpillar generally by using pesticides. Each farmer has various preferences in using pesticides to eradicate the Grayak caterpillar as a result of the increasing temperature.

Since rising temperatures occur, the use of pesticides has become more unrestrained by farmers. This was because the population of the caterpillar was higher due to the temperature is hotter than usual. This condition encourages farmers to increase the dosage of pesticides they used to handle the caterpillar population explosion.

\subsubsection{Usage of Land Processing}

The phenomenon of climate change in Larangan Village is the increasing rainfall and rainy days. It causes the land condition wet and difficult to cultivate. In the dry season, farmers are easier to cultivate land compared to the rainy season. In the dry season, the ground is only enough to be hoed twice. While in the rainy season, wet soil should be hoed at least three times in order to minimalize the moisture. This way, the use of hoist labor is also increasing that it will also affect the capital issue.

The highly frequent rainy days and intense rainfall in Larangan Village in the past 5 years have caused the land of shallot cultivation to become softer and the fertility level decreases. Therefore, the farmers' adaptation in the current cultivation of the fields is to increase the amount of labor to hoe the soil compared to previous conditions. Land conditions that are increasingly difficult to be processed due to climate change make farmers have to hire more hoe workers up to 10 people for the processing of land area of $0.25 \mathrm{Ha}$. In contrast, when the condition of the soil is still easy to process, farmers only need to employ 8 workers. The addition of this workforce can be interpreted as a form of adaptation of farmers in facing one of the consequences of climate change.

\subsubsection{Agricultural Financing}

Related to the climatic conditions in Larangan Village, when the dry season comes, farmers will spend twice as much as the capital to buy pesticides. It is because the caterpillar attacks are quite high at high temperatures. Moreover, the price of shallot seeds when the research took place was quite expensive. The form of financial strategy related to the impact of climate change by the farmers of Larangan Village is by storing the harvest. As for the other strategies, they are carried out by the farmers simply because they are viewed as a result of having limited capital instead of the impact of climate change.

Economic motivation is more strongly found in the practice of farming activities especially in terms of financing compared with motivation to improve agricultural conditions due to climate change. In general, adaptation by farmers is done spontaneously (autonomously) as encountered in small farmers in some areas. Below is the table on farmers' adaptation strategy in the agricultural financing aspect, where not all financing adaptation strategies are related to the motivation to secure the farm result due to climate change. 
Table 3 Farmers' Adaptation Strategy in Agricultural Financing Aspects

\begin{tabular}{clccc}
\hline No & Adaptation Strategies & Yes (\%) & No (\%) & Amount (\%) \\
\hline 1 & Agricultural credit (bank) & $38(38,4)$ & $61(61,6)$ & $99(100)$ \\
2 & Informal loan & $50(50,5)$ & $49(49,5)$ & $99(100)$ \\
3 & Crop saving *) & $28(28,3)$ & $71(71,7)$ & $99(100)$ \\
4 & Directly sold & $83(83,8)$ & $16(16,2)$ & $99(100)$ \\
5 & Debt to fertilization seller & $26(26,3)$ & $73(73,7)$ & $99(100)$ \\
6 & Others & $11(11,1)$ & $88(88,9)$ & $99(100)$ \\
\hline
\end{tabular}

*) Farmers' strategy due to the climate change phenomenon.

\subsubsection{Agricultural Credit}

Based on observations and interviews with the related informants in Larangan Village, there is no specific financing that has been provided to assist farmers who suffered from climate change losses. In the summer, as many as $38.4 \%$ of respondents rely on lending institutions to get initial capital to pay for labors, buying seeds and purchasing pesticides. This capital loan is not a specific agricultural credit.

Based on the observations in Larangan Village, there are no special credits of agriculture to cope with farmers' losses due to climate change. About 2 years before this research, there was once an agricultural loan called PUAP (Rural Agribusiness Development). However, the program did not run well because the farmers were not familiar with the administrative procedures. Similarly, the research done by Husena [7] on the adaptation of farmers in Sumedang Region, describes that in Sumedang area there is no special agricultural credit. There is only one program named PUAP which is increasingly abandoned by farmers due to complex administration processes and collateral systems. Farmers prefer to borrow loans from banks such as Kopabri program and Koferi by mortgaging Proof of Ownership of Motor Vehicles (BPKB) as an alternative form of borrowing loan to formal institutions. If farmers get the sale of shallot after harvest time, then they redeem their motorcycle BPKB that has been mortgaged.

\subsubsection{Informal Loan}

Based on interviews, the informal loan is also an alternative for shallot farmers in Larangan Village in obtaining capital in shallot farming. A total of 50 farmers prefer to obtain capital by borrowing a loan from relatives. Usually, this is done by old farmers who borrow funds from their children. However, if they asked further, this informal loan has nothing to do with losses on climate change. This informal loan process is generally done due to the lack of capital for farming. This case is often faced by farmers, especially when the price of fertilizers and pesticides is getting higher.

\subsubsection{Crop Saving}

At a time when shallot prices are low, farmers prefer to keep the shallot crops rather than selling them. They do hope that the shallot price will be increased if they postpone the shallot selling for about several weeks after harvesting. Farmers also save about 30\%-50\% of the harvest to be used as seeds that will be planted in the following planting season.

Fig. 1 shows the storage of shallot called para-para. Para-para is a storage container for the shallot that has been harvested. Typically, these bamboo-based entrants are arranged and woven like wooden shelves. Para-para is placed under the roof of the kitchen and above the stove. The placing of para-para on the stove is intended to gain the high temperature of the stove. The high temperature of the furnace will be useful in the process of storing the shallot. It will reduce the moisture of the shallot, kill deadly diseases that may still exist on the bulb of the shallot after harvesting. Shallot stored using para-para can last for about 4-6 months. 


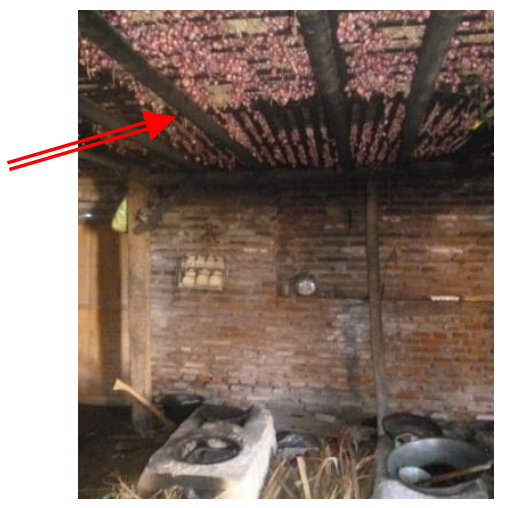

Fig. 1 Para-para

The strategy of storing shallots in para-para is a strategy for farmers to keep their shallot from being exposed to diseases caused by high humidity. This storage strategy has always been conducted a lot. However, this strategy was recognized by farmers increasingly since 2010. In every rainy month which is impossible for farmers to dry the shallot under the sun, most of the farmers will use para-para. In other words, the strategy of storing shallot on para-para is a farmers' adaptation strategy due to the conditions of climate change.

\subsubsection{Direct Selling}

The high intensity of rainy days in Larangan Village causes some farmers to have difficulty storing crops at home. There are $83 \%$ of respondents prefer to sell crops directly with the debt system rather than storing the crops first and then selling the crops when the price is higher. They do not care whether they can get high or low selling prices. This is because the farmers want to immediately pay the debt to the bank or relatives of the results of trying onion farm. Generally, the character of farmers who directly sell their crops is small farmers who do not want to take risks.

\subsubsection{Agricultural Diversification}

Agricultural diversification consists of horizontal and vertical diversification, including migration and wander. In the context of the impact of climate change on shallot farm in Larangan Village, shallot farmers use the adaptation strategy by planting crops other than shallot (horizontal diversification) and wander. Meanwhile, the strategy of working other than being a farmer (vertical diversification) is done because of the economic impulse. The division of adaptation strategies in the aspect of agricultural diversification by shallot farmers in Larangan Village is presented in the following table.

Table 4 Farmers' Adaptation Strategy in Agricultural Diversification Aspects

\begin{tabular}{clccc}
\hline No & \multicolumn{1}{c}{ Adaptation Strategy } & Yes (\%) & No (\%) & Amount (\%) \\
\hline $\mathbf{1}$ & Horizontal diversification (commodity)*) & $88(88,9)$ & $11(11,1)$ & $99(100)$ \\
$\mathbf{2}$ & Vertical diversification (Other jobs) & $39(39,4)$ & $60(60,6)$ & $99(100)$ \\
$\mathbf{3}$ & Migration (wandering)*) & $27(27,5)$ & $72(72,5)$ & $99(100)$ \\
\hline *) Farmers' strategy due to the climate change phenomenon. &
\end{tabular}

\subsubsection{Horizontal Diversification}

Horizontal diversification by shallot farmers in Larangan Village is conducted based on the consideration of the season. Horizontal diversification is the farmers' strategy in facing the impact of climate change by planting commodities other than main crops. For the rainy season and several months in the dry season, farmers prefer to grow rice instead of shallot. This is done by farmers to reduce the risk of possible harvest failure or crop decreasing if they force to plant shallots in those seasons. In addition to growing rice, farmers also grow sweet corn or peanuts in consideration because sweet corn and peanuts are more weather resistant. Moreover, planting sweet corn and peanuts are not as difficult as planting shallots in term of maintenance. It will be more difficult especially in times of uncertain climatic conditions. In addition, the capital spent to grow sweet corn is much cheaper than planting shallot. 


\subsubsection{Vertical Diversification}

As many as $39 \%$ of respondents have various vertical diversification. Most of the respondents become porters, shallot sellers, fishermen, drug traders and agricultural fertilizers, and other occupations both in Larangan Village and outside of Larangan Village. The diversification of these livelihoods was recognized by farmers as motivation to earn more income outside agriculture. This strategy has been done by people in Larangan since a long time ago. Consequently, if it is related to a strategy due to climate change impacts, livelihood diversification is not directly undertaken by farmers due to climate change conditions. It is more because of the economic motivation to earn more income.

\subsubsection{Merantau (Seasonal Wandering)}

The condition of water shortage often occurs in the agricultural area of Larangan Village even though the span of the dry season becomes shorter since a few years ago. This water shortage occurs especially in areas far from water sources such as rivers. Therefore, some shallot farmers prefer to find jobs outside the city.

There are $27 \%$ of respondents that chose to wander out of town. Generally, farmers who migrate are farmers who do not have the capital for the following crops during the dry season. It is because the cost of farming in the dry season is quite high, especially for irrigation (when there is no water). Farmers wander out of town like Banyumas and Jatibarang. They work there as sugarcane loggers for 1 month. In addition, other farmers wander to the area of Majalengka as a porter in Jakarta. Wandering is indeed an activity of economic fulfillment of family needs that farmers have done since before agricultural conditions occurred due to climate change. However, based on interviews with respondents who wander outside their area (especially seasoned migrants), they wander outside their area due to the drought in their rice fields. This condition has lasted for 2 years because the drought season is getting worse. Consequently, the farmers wander once in a year when the dry season arrives. Then after the rainy season arrives, they return to their home areas to farm again. Respondents who do this wandering activity are respondents whose land ownership is less than $0.1 \mathrm{Ha}$.

\subsubsection{Knowledge and Social Networking Aspects}

Knowledge and social network are defined as all forms of knowledge of farmers either from the farmers themselves or from others in forming the farmers' adaptation. In this aspect of knowledge and social network, there are identified four issues: farmers' knowledge about planting and harvesting times, farmers' knowledge of climate change and handling, farmers' participation in agricultural training, and farmers' activities in farmer groups.

Based on observations and interviews, farmers in Larangan Village have not yet adapted the knowledge and social network aspects related to the impact of climate change on shallot farming. The four strategies are still limited to the knowledge and its activities of farmer groups in general.

Table 5 Farmers' Adaptation Strategy in Knowledge and Social Networking Aspects

\begin{tabular}{llccc}
\hline No & \multicolumn{1}{c}{ Adaptation Strategy } & Yes $(\%)$ & No (\%) & Amount (\%) \\
\hline 1 & Knowledge about planting and cropping time & $73(73,7)$ & $26(26,3)$ & $99(100)$ \\
2 & Knowledge about climate change and its handling & $15(15,2)$ & $84(84,8)$ & $99(100)$ \\
3 & Participation in agricultural training & $20(20,2)$ & $79(79,8)$ & $99(100)$ \\
4 & Participation in farmers group & $34(34,3)$ & $65(65,7)$ & $99(100)$ \\
\hline
\end{tabular}

\subsubsection{Knowledge about Planting and Cropping}

Public knowledge is generally inseparable from the influence of local or indigenous knowledge that develops in the community. Based on this research, $73.7 \%$ of farmers know the time of planting and harvesting in accordance with shallot cropping conditions only based on their own experience of planting shallot. It is because the farmers have a benchmark time in planting the shallot in accordance with existing habits.

In Larangan, there are different customs with other villages. There is a term called "Lerengan" or slopes or "Nglereng", which is in the rainy season, there are some farmers who actually instead plant shallots. Meanwhile, at that time most farmers generally choose to plant paddy. The community of Larangan usually call this term as a kind of farming that challenges the climate. This slope is usually done 
by farmers who have large capital to prepare drainage, to buy fertilizer and medicine diseases at a more expensive price. Several farmers do this because almost during the rainy season, the supply of shallot becomes lower than the usual. The lower the supply, the higher the selling price will be. Then several farmers are motivated to gain a big profit by doing slope. This knowledge is still known in farmers there and used as a benchmark in planting shallots. Despite the current uncertain rainfall and rainy days, farmers tend to keep using the benchmark that they usually do.

\subsubsection{Knowledge about Climate Change and its Handling}

Farmers' knowledge of the climate change condition in Larangan Village is still not very popular. Approximately only $15.5 \%$ of farmers are aware of the effects of climate change on shallots, for example, high temperatures will cause an increase in the population of caterpillars and shallot tubers to grow less than the usual with unpredictable weather as happened in 2-5 years ago. However, farmers still do not know how to handle plants affected by climate change very well. They have been relying on the provision of insecticide drugs as a solution to eliminating the growing number of caterpillars caused by high temperatures.

\subsubsection{Participation in Agricultural Training}

Based on information from informants, a total of 20 farmers participated in the agricultural training. This agricultural training is called Good Agriculture Practice Field School (SL GAP). This activity is done in 2012 within 1 month. In $S L$ GAP farmers are taught how to cultivate proper farming. This training is given only to members of farmer groups only. Farmers outside the group were not given access to this training.

Related to climate change conditions, the Department of Agricultural Food and Horticultural Crops of Brebes District organizes SLI (Climate Field School) in several areas. However, this SLI has never been held in Larangan Village. This is because the department considers technical factors such as distance from the office to the village in conducting this training.

The farmers' knowledge of the knowledge and social network in the Larangan Village has not been referred on the condition of climate change. In other words, there is no farmers' adaptation strategy to climate change in the aspects of knowledge and social networks. This fact is reinforced by the information from the agricultural extension of Larangan Village and the Department of Agricultural Food and Horticultural Crops of Brebes District, that the farmers have not been given the information about climate change either in terms of handling problems or case example.

\subsubsection{Participation in farmers group}

Around 34 respondents are members of farmer groups. In general, the presence of group members at the meeting is quite active. However, the amount of group members who present in the monthly meeting is not always the same. In the interaction of group members, there is an exchange of information related to farming, especially on the usage of new pesticides or on the sale price of shallots. Unfortunately, the group members do not discuss the specific matters in handling the impacts of climate change. The handling of the impacts of climate change has not been discussed in both the farmers' group or community. All adaptation actions are limited to individuals and uninitiated in groups. This is as expressed by one of the farmer group members. He explained that there has been no special attention and discussion in the farmer group on the impacts of climate change.

\section{Conclusions}

The adaptation strategies of shallot farmers toward climate change phenomenon in Larangan Village on direct case consisted of several aspects; cultivation aspect (changing the planting pattern, using the pump, changing the land management, and increasing the utilization of pesticide), agricultural financing aspect (storing shallot in para-para), and cultural diversification aspect (horizontal diversification/planting other commodities and seasonal transmigration). 


\section{References}

1. Adger, W.N., Huq, S., Brown, K., Conway, D., Hulme, M.: Adaptation to climate change in the developing world. Prog. Dev. Stud. 3, 179-195 (2003)

2. Kurukulasuriya, P., Mendelsohn, R.: A Ricardian analysis of the impact of climate change on African cropland (Policy Research Working Paper 4305). , Pretoria (2007)

3. Malik, A., Qin, X., Smith, S.C.: Autonomous Adaptation to Climate Change: A Literature Review (Institute for International Economic Policy Working Paper Series-2010-27). , Washington DC (2010)

4. Bradshaw, B., Dolan, H., Smit, B.: Farm-level adaptation to climatic variability and change: crop diversification in the Canadian prairies. Clim. Change. 67, 119-141 (2004)

5. Nhemachena, C., Hassan, R.M.: Micro-Level Analysis of Farmers' Adaptation to Climate Change in Southern Africa (IFPRI Discussion Paper 00714). , Washington DC (2007)

6. Nurasa, T., Iqbal, M.: Adaptasi dan Antisipasi Petani Serta Strategi Penerapan Usaha Tani Dalam Mengatasi Fenomena Perubahan Iklim Di Provinsi Nusa Tenggara Timur. J. Sosio Ekon. (Journal Socio Econ. 15, (2012)

7. Husena, C.: Adaptasi Petani Tanaman pangan Dalam Menanggapi Dampak Perubahan Cuaca (Studi Kasus : Desa Situ Raja, Kabupaten Sumedang), (2012)

8. Ifeanyi-obi, C.C., Etuk, U.R., Jike-wai, O.: Climate Change, Effects and Adaptation Strategies: Implication for Agricultural Extension System in Nigeria. Greener J. Agric. Sci. 2, 053-060 (2012)

9. Deressa, T.T., Hassan, R.M., Ringler, C.: Perception of and adaptation to climate change by farmers in the Nile basin of Ethiopia. J. Agric. Sci. 149, 23-31 (2011)

10. Kurniawati, F.: Pengetahuan dan Adaptasi Petani Sayuran Terhadap Perubahan Iklim, (2012)

11. Oyekale, A.S., Oladele, O.I.: Determinants of climate change adaptation among cocoa farmers in southwest Nigeria. ARPN J. Sci. Technol. 2, 154-168 (2012)

12. Ridwan, E.A.K.: Cara Menggunakan dan Memakai Analisis Jalur (Path Analiysis). Alfabeta, Bandung (2008)

13. Below, T., Artner, A., Siebert, R., S, S.: Micro-level Practices to Adapt to Climate Change for African Small-scale Farmers (IFPRI Discussion Paper 00953). , Washington DC (2010) 